\title{
Trilogie Zeměmoři Ursuly K. Le Guinové jako podobenství o hledání, nalézání a podstatě lidskosti
}

Luisa Nováková

\begin{abstract}
Ursula K. Le Guin's Earthsea Trilogy as a Parable of Searching, Finding, and the Essence of Humanity

The study focuses on Ursula K. Le Guin's Earthsea Trilogy, the novels A Wizard of Earthsea, The Tombs of Atuan and The Farthest Shore, as a distinctive, symbolic testimony of human fragility and strength. It wonders whether the works were written for young people or for adults. On the basis of the analysis, it concludes that the text can be regarded as a modern parable.
\end{abstract}

\section{KEYWORDS}

Ursula K. Le Guin, A Wizard of Earthsea, The Tombs of Atuan, The Farthest Shore, literature for children and youth, fantasy.

\section{KLÍčOVÁ SLOVA}

Ursula K. Le Guinová, Čaroděj Zeměmoří, Atuánské hrobky, Nejvzdálenější pobřeží, literatura pro děti a mládež, fantasy.

O zeměmořském cyklu Ursuly K. Le Guinové bylo už napsáno velmi mnoho, samozřejmě především v angličtině. U jedné z čelných, dokonce zakladatelských osobností soudobé fantasy a science-fiction to nepochybně nepřekvapí. Dokonce sama autorka se $\mathrm{k}$ důvodům a procesu tvorby těchto textů vyjádřila v knize Earthsea revisioned (1993). České zdroje o Zeměmoří sice nemlčí - nelze 
přece pomíjet základní kameny žánru -, zároveň se mu však věnují jen okrajově, zpravidla pouze konstatací potvrzují jeho důležitost pro žánr fantasy, na pozadí jiných témat, pro ně úhelných. A zatímco ve vlasti se nakonec dostalo Ursule Le Guinové všeobecného uznání odborné veřejnosti (míním zde nejen titul Living Legend, udělený autorce Knihovnou amerického Kongresu v roce 2000 za přínos americké kultuře, ale především udělení plakety National Book Award v roce $2014^{1}$ ), u nás zůstává reflektována (nebo spíše připomínána) pouze specialisty na fantastiku.

Proto je, zdá se mi, možné přidat $\mathrm{k}$ mnohému v angličtině napsanému o Zeměmořské trilogii pár slov v češtině.

Chci se podívat na zeměmořskou trilogii, tedy knihy Čaroděj Zeměmoří ( $A$ Wizard of Earthsea, 1968) ${ }^{2}$, Atuánské hrobky (The Tombs of Atuan, 1971) ${ }^{3}$ a Nejvzdálenější pobreží (The Farthest Shore, 1972) ${ }^{4}$, především jako na svébytnou, symbolickou výpověd’ o křehkosti a síle člověka. A protože je zeměmořská trilogie řazena mezi texty určené, dokonce intencionálně, mladému čtenáři („Nejslavnější jsou [její] fantasy př́iběhy pro mládež, známé jako Earthsea Trilogy - Zeměmořská trilogie, které však oslovily i mnohé dospělé čtenáře," píše např. autorka slovníkového hesla věnovaného Ursule Le Guinové ve Slovníku autorů literatury pro děti a mládež Jana Sladová /SLADOVÁ 2007: 507/), dotknu se rovněž otázky cílového vnímatele.

Zaměříme-li se na kompozici trilogie, potkáme se ve všech případech s velmi prostým tvarem, lineárním, chronologickým vyprávěním, které vykazuje v Čaroději Zeměmoří a Nejvzdálenějším pobřeží, opřených o motiv cesty, dokonce tendence $\mathrm{k}$ epizodičnosti. Tato epizodičnost je $\mathrm{v}$ některých př́ipadech pouze zdánlivá - co se zdá být v jednom díle toliko epizodou dokreslující linku putování hrdiny či hrdinů, vrátí se v díle jiném s novou naléhavostí a novými dějovými atributy a pomáhá trojici jinak zcela samostatných knih scelit.

Zvláště markantní roli v tomto směru hraje setkání hlavní postavy, čaroděje Geda, s dvojicí starých lidí na opuštěném ostrově: v první knize mu tito staří zachrání život a od ženy dostane podivný dar, úlomek amuletu, na nějž je však upřena vypravěčova i čtenářova pozornost pouze letmo a posléze je od něj naprosto odvedena dalšími, pro daný díl důležitějšími, peripetiemi a motivy,

1) K tomu viz autorčinu řeč při převzetí ceny (Le GUINOVÁ 2016: 244-245).

2) Česky poprvé 1992.

3) Česky poprvé 1994 pod názvem Hrobky Atuánu.

4) Česky poprvé 1995. 
v druhém svazku se však útržek nedokončeného příběhu vrací, stává se důvodem Gedovy cesty do Atuánu - a v poslední knize trilogie se jako znak úzce svázaný s bájnou královskou mocí stane atributem spojeným s kýženým návratem zeměmořského krále. A mohli bychom uvést další příklady takto fungujících motivů či epizod, poněvadž zvláště mezi prvním a posledním dílem trilogie nacházíme spojnic mnoho, $\mathrm{z}$ určitého úhlu pohledu můžeme dokonce uvažovat o paralelismu svého druhu. ${ }^{5}$

Zdaleka ne všechny epizody či útržky příběhů však slouží naznačeným zpơsobem. Vedlejší postavy se mnohdy objeví náhle a vytratí se hned poté, co sehrají roli podstatnou pro posunutí hlavního děje, stanou se pozadím pro ozřejmení charakteru či vnitřního světa hlavních postav, nebo jim pomohou v jejich proměnách a zrání. Tento postup připomene postupy známé $\mathrm{z}$ klasické dobrodružné literatury 19. století ( $v$ níž sloužil mimo jiné k utvrzování čtenářovy interpretace hlavní postavy, vytvářené zpravidla jako postava-definice), ale také postupy mýtů, rytířských romancí a kouzelných pohádek. ${ }^{6}$

Ursula Le Guinová potenciálu jednotlivých epizod, či „zastavení na poutnických cestách" využívá zároveň k dotváření pestrosti, barvitosti a jedinečnosti obrazu svého fikčního světa. ${ }^{7}$ Prostředí, v nichž se odehrávají, se neopakují, jsou originální a Le Guinová, která patři k mistrům evokace, zde - opět velmi jednoduchými prostředky - dokazuje nemalou míru svého básnického talentu. ${ }^{8}$

5) Základní syžetová linie je rozhodně výrazně podobná, v obou případech je opřena o putování, cestu či bloudění, cestu s iniciačními rysy, v obou na konci čeká nutnost vypořádat se s největším možným zlem a vstoupit na hranice světa, dokonce je překročit. Vše ostatní, veškerý další děj, se úzce přimyká k této základní lince, podporuje ji, dokresluje, a právě proto vykazuje tak značnou epizodizační tendenci.

6) K lidové pohádce přitom odkazují i některé drobné, podle mého soudu víceméně vnější rysy, a to v Čaroději Zeměmoří velmi výrazný numerický kompoziční princip opřený o číslo tři, přičemž se objevuje jak v souvislosti s podstatnými, dokonce nejdůležitějšími zápletkami (např. potřikrát temná bytost pronásledující protagonistu vžene Geda do pasti a ohrozí ho na životě, tři dny trvá závěr čarodějovy honičky za Stínem na hranice světa), i s drobnými, vedlejšími epizodami (např. hned několikrát se čtenář dovídá, že Ged strávil někde právě tři dny, tři dny věnoval určité činnosti - byt je to $v$ př́ípadech, kdy je přesný počet v podstatě naprosto irelevantní). Ke srovnání pohádky a fantasy obecně viz více NovÁKovÁ 2016. Dokonce i aluze na antickou mytologii se trilogií Le Guinové přinejmenším mihnou: poznačený antickým dědictvím je prokazatelně především motiv labyrintu v Atuánských hrobkách, což dokládá, mimo jiné, okrajový a pouze ozvláštňující - v ději nevyužitý - motiv Ariadniny niti (i Tenar při svých cestách labyrintem užívá niti jako záchranného vodítka), obraz království mrtvých v Nejvzdálenějším pobřeží, krajiny stínů těch, kdo zemřeli, nápadně připomíná starořímské představy o zásvětí, byṫ podobnost je do značné míry vnější představa posmrtné existence, kterou Le Guinová naznačuje, je totiž naprosto odlišná. Ozvuk artušovských mýtů - a s nimi středověké rytířské romance - potkáme v epizodě o paní Serret a kameni Terrenonu (srov. LE GUINOVÁ 2002: 100 nn, především kapitoly Pronásledovaný a Let sokola).

7) A byl to právě on, který čtenáře - i značnou část hodnotitelů - oslovil nejdříve a nejdůrazněji.

8) Srov. DĚDINOvÁ 2018a: 148 - „Le Guinová mistrovsky dokáže několika slovy vyvolat živoucí obraz zpřítomňující se ne pouze před očima, ale postihující vjemy dalších smyslů. Přes něj se dostává k emoci [...], skrze niž propojuje fikční svět vyprávění a čtenářovu zkušenost aktuálního světa.“ 
Z dokonale zachycených úlomků skládá vypravěč v čtenářově představě mozaiku, scelující se postupně do jednolitého obrazu Zeměmoří.

Tento obraz však není pro text rozhodně nejdůležitější, autorský záměr, jako u ostatních textů Le Guinové, směřuje jinam - a to, co je nejnápadnější na první pohled, prritáhne $\mathrm{k}$ sobě pozornost při prvním čtení, tvoří pouze rámec autorské výpovědi.

$Z$ výše řečeného plyne, že ačkoli bývají knihy trilogie někdy označovány za romány, románovou stavbu nemají - označení tedy podporuje pouze rozsah textů, ačkoli ani ten ne přesvědčivě (pohybuje se na hranici dvou set tiskových stran). Prostřední díl, Atuánské hrobky, bychom především díky jeho sevřenosti mohli označit za novelu, u Čaroděje Zeměmoří a Nejvzdálenějšího pobřeži však ani toto není možné.

Každopádně prostá, zcela přehledná kompozice, bez dějových odboček, bez retrospektiv, bez anticipací, soustředěná výhradně na jednu dějovou linii spojenou s hlavními postavami je čtenářsky nenáročná, a pokud bychom trilogii hodnotili pouze $\mathrm{z}$ tohoto úhlu pohledu, poslouží nám naše konstatování jako zřejmý důkaz, že skutečně máme před sebou knihu pro dětského čtenáře. ${ }^{9}$

Zmíněnému čtenářskému určení napovídají v textech také další aspekty. Především ve všech třech najdeme referenčního hrdinu, jehož přítomnost je základním kamenem definice příběhové prózy ze života dětí a mládeže. ${ }^{10}$

V Čaroději Zeměmoři je do této role obsazen přímo titulní hrdina, v Atuánských hrobkách ho vystřídá mladinká velekněžka Tenar - a s její postavou vstoupí do trilogie, naprosto nepřehlédnutelně, mnoho rysů spojovaných tradičně s př́iběhovou prózou s dívčí hrdinkou, včetně křehkého milostného motivu - a v závěrečném díle trilogie uvádí Le Guinová na scénu sedmnáctiletého následníka trůnu Arrena. ${ }^{11}$ V̌sichni tři procházejí iniciační cestou svého druhu (nejvýraznější, dokonce místy doslova modelové iniciační rysy přitom vykazuje příběh Gedův) - a byt se tato cesta, řízena logikou konkrétního př́iběhu, v jednotlivých př́padech proměňuje, intenzita hledání je u každé postavy jiná a jiná je také míra konečné proměny nitra a nalezení sebe sama - směr iniciačního procesu

9) K autorskému záměru, intencionalitě trilogie i ke genezi jejího vzniku se autorka vyjádřila mj. v přednášce Mladý dospělý v „young adult" literatuře (LE GuINovÁ 2019: 147-163).

10) Mísení příběhové prózy s pohádkou a dalšími př́ibuznými žánry je přirozené už od počátku jejich moderní historie - a pro literaturu současnou (míněno přinejmenším od poloviny 20. století) dokonce typické.

11) Věk jednotlivých postav - pomineme-li v případě Geda a Tenar expoziční kapitoly, v nichž provází vypravěč čtenáře jejich i dětstvím -, které stojí na prahu dospělosti, přitom implikuje čtenáře výrazně staršího, než by odpovídalo jejich kompoziční jednoduchosti. I tato skutečnost dokládá, že dílo Le Guinové se obvyklým literárněteoretickým poučkám vymyká. 
i jeho výsledek jsou v základě stejné. Nepřehlédnutelné iniciační rysy, přirozeně blízké čtenářrom $\mathrm{v}$ době dospívání, s nimiž fantasy pro mládež i proto ráda a velmi často pracuje, jsou dalším podpůrným důkazem pro případné tvrzení, že je zeměmořská trilogie dílem pro děti a mládež.

Jenže věc opět není tak jednoduchá, jak by se mohlo na první pohled zdát. Zpochybnitelná jsou i tvrzení, která potkáme např. v recenzích (či spíše hodnotících zprávách) o díle na českém internetu, že totiž máme před sebou epickou fantasy, že zeměmořská trilogie „nese veškeré její znaky“. Prosazující se označení epická fantasy užívané pro fantasy opřenou o dobrodružný děj totiž opět u zeměmořské trilogie platí pouze s výhradami.

Už bylo řečeno, že děj, ač poutavý a barvitý, je v podstatě jednoduchý - a především se zcela vzdává některých typických momentů, $\mathrm{k}$ takovému typu prózy přináležejících. Z hlavního záběru na rovinu pouhé konstatace např. odsouvá motivy zaslouženého vítězného triumfu postav, ponechává je stranou jako cosi (nejen) pro příběh nepotřebného. Příběhy se uzavírají bez halasu, v intimitě, tiše. Podobně Le Guinová buduje obraz svých postav. To, co by pro skutečně epickou - přeložme si pomůckově dobrodružnou - fantasy bylo svádivě nepřehlédnutelné a stěží pominutelné, ona úmyslně opomíjí.

Nahlédneme-li trilogii jako svého druhu celek spojený postavou čaroděje Geda, vyplyne tato skutečnost na povrch velmi zřetelně. V prvním díle to tak očividné není (sledujeme cestu mimořádně talentovaného chlapce od podrážděné dětinské pýchy $\mathrm{k}$ plné a dospělé lidské zralosti), ale v rámci trilogie už je patrné, co z životního příběhu svého protagonisty Le Guinová zdůrazňuje, čemu věnuje pozornost, a co naopak upozad’uje. Vybírá sice vždy sekvence (a úmyslně volím toto slovo, poněvadž i trilogie jako celek vykazuje jisté znaky epizodičnosti, ostatně, jak už bylo řečeno, díly jsou sice provázány, fungují však zároveň zcela samostatně) klíčové, ale klíčové především z hlediska vývoje postavy, stranou zůstává jakákoli, byt’ sebepochopitelnější vnější okázalost.

A tak se v druhém a třetím díle dozvíme $z$ úst vypravěče, že se hrdina vstupní knihy stal největším z mágů Zeměmoří, arcimágem, posledním žijícím drakopánem - a jako čtenáři shledáváme, že jsme v předešlém ději byli svědky zárodků či důvodů těchto vyústění -, skutečnost sama však není nikterak glorifikována, není jí prakticky věnována pozornost, přinejmenším pozornost odpovídající převládající praxi žánru, stává se toliko jedním z atributů postavy, připomínajícím, zdůvěrňujícím a ukotvujícím její cestu od překročení hranice $k$ dospělosti až na hranici mezi středním věkem a počínajícím stářím. Podobně postupuje Guinová v Atuánských hrobkách, kde „upře“ čtenáři pohled na zasloužené ocenění hlavních postav těmi, 
pro něž se obětovaly, a ještě výrazněji se její pohrdání vnějškovostí projeví v posledním díle, $v$ němž využívá už od Tolkienových dob oblíbený ( $a$ už před Tolkienem známý) motiv návratu krále. Dospívající Arren je sice potomkem bájného krále a čaroděje a jeho nástup na trůn Zeměmoří potvrdí splněná dávnověká věštba - ale o samotném nastolení krále se čtenář nedoví víc, než že se uskutečnilo. Le Guinovou naprosto nezajímají podrobnosti, rezignuje na čtenářská očekávání a opouští zde dokonce svým způsobem „realistickou“logiku příběhu (vždyt̉ podle vnitřní logiky tohoto textu je stěží možné, aby pouhé splnění proroctví, zůstalo-li do značné míry skryté, neefektní a beze svědků, stačilo k nastolení chlapce, byt s královskou krví, na osm set let uprázdněný trůn).

Ve všech těchto případech nejde o autorskou lenost nebo chybu, jde o jasný záměr - potlačením toho, co je na povrchu efektní, dokonce mnohdy fungující u jiných autorů jako vrchol vyprávění, nahrazením očekávaného úspornou konstatací, zdůrazňuje Le Guinová, co je pro vyznění textů podstatné a co je pod povrchem ukryto - podobně jako bývá ukryto nejzásadnější pod povrchem pozlátka ve skutečném životě. Pocty, veřejné ocenění zásluh, oslavy, odměny či vavříny jako by pro postavy Le Guinové nic neznamenaly (byt’ vzhledem k tomu, za jaké skutky se jim jich dostává, nejsou vypravěčem zapomenuty a postavy se jim nebrání ani jimi nepohrdají) - je jim vykázáno místo na okraji, ve stínu toho, na čem postavám, a autorce samé, opravdu záleží.

Také tato akcentace - nebo v tomto případě přesněji potlačení očekávaného akcentu - o charakteru textu ledacos vypovídá. Zdůrazňuje se jím ještě zásadněji předkládaná hodnotová hierarchie a podporuje úspornost a sevřenost vyjádření.

A co tedy naopak pro Le Guinovou v zeměmořské trilogii podstatné je?

V prvním díle trilogie mladinký Ged, podléhaje ještě napolo dětské (ale navzdory obvyklejšímu výkladu o nic méně závažné) pýše na vlastní, mimořádné, schopnosti a touze „ukázat se“, zvítězit v pomyslném souboji nad chlapeckým rivalem, vyvolá nepojmenovatelné zlo, ohrožující nejen jeho, ale také ostatní. Čeká ho nejprve bolestný, zničující útěk před démonickým stínem - a posléze, když se mu odhodlá postavit tváří v tvář, hon na probuzené zlo, hon, na jehož konci ho může čekat velmi snadno vlastní smrt, hon na sám konec země, s odhodláním sprovodit ze světa, co na něj přivedl, i za cenu svého života. Stín, zosobněný Gedův strach ( $z$ otce, jenž pro něj neměl pochopení, z nájezdníků, jejichž vpád zažil v dětství, nejniternější, ukrývaný strach spojený s bytostnými zraněními), nabývá posléze tvar Gedova osobního zla, je zpřítomněním jeho Gedovy nejtemnější strany - a hledané jméno stínu, kterým v závěru příběhu 
Ged stín, zrcadlící víc a víc mladíkovy rysy, osloví, aby nad ním získal moc a tím ho porazil, je jeho vlastní. Toto sebepřijetí přitom neznamená ani v náznaku smíření se se zlem, které žije v nás a z nás vychází, znamená poražení pýchy, konečné popření falešného obrazu o dokonalosti sebe sama, přijetí vědomí vlastní nedokonalosti a uvědomění si, jak křehká je hranice mezi dobrem a zlem. Ged tak na konci prvního dílu trilogie nevítězí mocí svého magického umění, silou ani chytrostí, vítězí pokorou a ochotou podívat se tváří v tvář sám sobě (a to především v zájmu druhých lidí, ohrožených nechtě, z hlouposti vypuštěným zlem) - ačkoli ho ten pohled může zahubit.

V Atuánských hrobkách se dívčí velekněžka nechá pohnout svědomím a soucitem s druhým člověkem a postaví se proti všemu, k čemu byla odmalička vychovávána, dokonce podle svého přesvědčení předurčena, čemu donedávna naprosto věřila. Ačkoli ztratí všechno, co do té doby tvořilo její svět, zachrání nejen druhého, ale i sebe sama, vymkne se z moci bezejmenných temných sil, jimž byla jako dítě obětována. A navíc získá svobodu.

V Nejvzdálenějším pobreží musí stárnoucí Ged provázený sedmnáciletým Arrenem dospět až na hranice světa živých, překročit je a postavit se smrti s ochotou k absolutní oběti, aby zastavil šírící se destrukci a zlo hrozící zcela rozvrátit svět Zeměmoří a lidi uvrhnout do zkázy nejen těla, ale především duše.

Ani jedna z těchto cest není jednoduchá, ani jedna není prosta bloudění a váhání, ani jedna nemá sebemenší záruku, že dospěje $k$ cíli - a všechny jsou velmi tiché. Třebaže ve svém důsledku ovlivňují budoucnost světa, jsou do značné míry soukromé, málem $v$ rámci fantazijního světa přehlédnutelné - a rozhodně až do vyvrcholení okolím přehlížené. V porovnání s typickým dobrodružným putováním a zápasem téměř „všedni““.

Ačkoli osamělost je příznačná jak pro Geda, tak pro Tenar, na svůj zápas nezůstávají postavy samy - nalézají rovnocenného spoluhráče, jehož blízkost, pomoc a vzájemná důvěra determinuje úspěch společného úsilí.

Už na základě letmého nastínění dějů jsou hlavní motivy a témata próz zřejmá. Do značné míry se v celé trilogii opakují, byt̉ samozřejmě variovaná, a opakováním se rovněž potvrzují.

Za klíčové lze pokládat motivy sebepoznání - hledání odpovědi na otázku „Kdo jsem?“, která však na konec zůstává zodpovězena jen zčásti (poněvadž toto hledání je úkol na celý lidský život); motivy odvržení pýchy a dozrávání k pokoře; odmítnutí egoismu a přijetí milosrdné lásky k druhým jako životního principu; ochoty obětovat se za jiné; připravenosti plnit povinnost; zodpovědnosti za 
vlastní činy; přátelství a důvěry mezi lidmi; úcty ke stvoření. Ty pak jsou doprovázeny motivem síly slova (který se s výše zmíněnými prolíná) a obdivem ke kráse, téměř její glorifikací. V posledním se Le Guinová nejpříměji projevuje jako rozená básnířka.

Při pohledu na celek nedávno uzavřeného díla Ursuly Le Guinové vidíme, že jde zhusta o leitmotivy její tvorby (z témat pro ni charakteristických je v trilogii méně akcentováno téma svobody), podání se však liší. Ačkoli máme před sebou texty vřazované do literatury pro mládež, Guinová je zde méně explicitní než v některých svých ostatních prózách, včetně těch nejoceňovanějších (podíváme-li se kriticky např. na romány Levá ruka tmy, Vyprávění nebo prózu Svět je les, les je svět, shledáme, že jde o texty psané do značné míry à la teze - a „pouze“ autorčin nepopiratelný umělecký talent je chrání od sklonu ke schematičnosti).

Etický rozměr Zeměmoří je samozřejmě nepřehlédnutelný, prostor pro vlastní hledání odpovědí, vlastní interpretaci je však mnohem větší. Pravděpodobně i proto, že zde Le Guinová nereflektuje vybrané konkrétní téma (jež je pojímáno jako její autorský, umělecký komentář k současnosti), ale dotýká se univerzálních, základních kamenů, na nichž stojí lidský život a především lidství jako takové. ${ }^{12}$

Zeměmořskou trilogii tedy můžeme označit za trojici novodobých podobenství. K žánru ukotvenému v evropské kultuře po celá tisíciletí díky podobenstvím novozákonním je přibližuje nejen symbolický, eticky apelativní obsah, ale v plném souladu s ním jednoduchá forma, která pomáhá porozumět sdělení, nevnucuje, vybízí $\mathrm{k}$ vlastnímu uvažování o sděleném a přirozenějšímu přivlastnění obhajovaných hodnot. ${ }^{13}$ Hodnoty, jež Le Guinová obhajuje, jsou přitom základními hodnotami skutečného lidství tak, jak je - i v souladu s naší, na křestanském základě postavenou kulturou - vnímáme. ${ }^{14}$

12) Navíc zjednodušujícím interpretacím zaměřeným pouze na snadné vyjádření „poselství“ beletristických textů autorka programově odporovala: „Představa, že příběh ,má poselství, předpokládá, že se dá zredukovat na pár abstraktních slov, úhledně shrnutých v písemném testu na střední nebo vysoké škole anebo věcné a stručné recenzi kritika. Kdyby to byla pravda, proč by spisovatelé podstupovali všechnu tu námahu s vytvářením postav, vztahů, zápletek, krajin a všech podobných věcí? Proč by prostě jenom nepředali poselství? Je snad příběh krabička, do které se schová myšlenka?" napsala v eseji Poselství o poselství (LE GuinovÁ 2019: 167).

13) Podobenství pak otevírá prostor i tolkienovské obnově (srov. TOLKIEN 2006, zvláště s. 163-169).

14) V interpretacích díla Ursuly Le Guinové bývají často připomínány, a právem, jiné než evropské myšlenkové a náboženské zdroje (srov. např. BERNARDO - MURPHY 2006). Mnohé lidské ctnosti jsou pak vnímány a hodnoceny stejně, nebo velmi podobně, jak v křestłanství, tak např. v buddhismu či taoismu, Le Guinové tak blízkém. Přesto podle mého soudu stojí za povšimnutí, že v zeměmořské trilogii nacházíme místa, která působí téměř jako svébytné parafráze novozákonních pasáží. Nade vším pak v tomto ohledu dominuje kristologický apel na to, že „kdo by chtěl svůj život zachránit, ztratí jej, kdo však svůj život pro mě ztratí [tj. pro bližního], zachrání si jej“. 
Přijmeme-li pohled na zeměmořskou trilogii jako na soubor podobenství, vrací nás dané pojetí k otázce cílového čtenáře - a ta se zdá najednou zcela jasná. Charakter podobenství vznikajícího typickým spojením jednoduchosti tvaru $s$ myšlenkovou závažností obsahu je předurčuje $k$ vnímání všemi věkovými skupinami, k návratům, přehodnocování závěrů, které $\mathrm{z}$ nich plynou pro život recipienta, novým interpretacím. Podstata sdělení se nemění, ale s přibývající životní zkušeností je jeho pochopení prohlubováno. Jinak promlouvají podobenství $\mathrm{k}$ dětem, jinak $\mathrm{k}$ dospívajícím, jinak ke čtenářùm stojícím společně s Gedem Nejvzdálenějšího pobřeži před hranicí stáří. Jsou otevřená všem. Otázka cílového čtenáře se tím u zeměmořské trilogie jeví jako téměř bezpředmětná a slovníkové „nálepky“ zbytečné. Ostatně sama Le Guinová jakákoli zjednodušující vymezení - a omezení - odmítala, i pokud šlo o věk čtenáře. „Většina fantastické literatury," tvrdí na př́klad, „dokáže překlenout hranice dané věkem čtenářů, což je v mých očích schopnost nanejvýš obdivuhodná“ (LE GuINOvÁ 2019: 59).

Ursula K. Le Guinová patří k autorům, kteří se rozhodli využít forem nabízených literární fantastikou, aby se otevřeně a svobodně vyslovili k nejbolestnějším otázkám současné společnosti. ${ }^{15}$ Trilogie Zeměmoří se vedle ostatní autorčiny tvorby minimálně v daném ohledu jeví mimořádně nenápadně, přes veškeré umělecké kvality je i proto odsouvána na druhou kolej zájmu literárních vědců. Přesto ani v ní se Le Guinová nezapřela a trilogie nabízí zcela jasnou odpověd', jaká cesta vede do budoucnosti. Není to odpověd', které by se naslouchalo snadno, budeme-li brát velká slova a velké požadavky naprosto vážně: Naději zachránit sebe i stvoření, říkají zeměmořská podobenství, máme jedině tehdy, vzdáme-li se svého sobectví a budeme ochotni obětovat dokonce sami sebe. A jedině tehdy, když to dokážeme, máme šanci vrátit se domů.

\section{PRAMENY}

Le Guinová K., Ursula

2002 Čaroděj Zeměmoří (Praha: Triton), vyd. 2., přel. Petr Kotrle

2003a Atuánské hrobky (Praha: Triton), vyd. 2., přel. Petr Kotrle

15) Nad možnostmi, které čtenáři nabízí fantastika při snaze lépe uchopit okolní svět, se zamýšlela řada spisovatelů, včetně samotné Le Guinové (viz LE GuINOVÁ 2019), i literárních vědců, a to z nejrůznějších úhlů pohledu. V poslední době tak z úhlu pohledu kognitivní vědy u nás učinila např. Tereza Dědinová: „Objektivní realitu nedokážeme uchopit přímo, pouze zprostředkovaně skrze pozorování, pocitování, myšlení a interpretaci. Naše zkušenost s realitou - neboli situační moment - je výslednicí množství rozličných vstupů. [...] Protože mozkové kognitivní obvody reagují na fikci (tedy představované) obdobně jako na skutečnost (tedy vnímané), čtení beletrie může mít značný vliv na naše chápání světa, ostatních lidí i nás samých," píše v závěru své studie (DĚDINOvÁ 2018b: 158). 
Luisa Nováková

Trilogie Zeměmoří Ursuly K. Le Guinové jako podobenství o hledání, nalézání a podstatě lidskosti

2003b Nejuzdálenější pobřeží (Praha: Triton), vyd. 2., přel. Petr Kotrle a Irena Přibylová

2016 Vyprávění (Praha: Gnóm!), přel. Jakub Němeček

\section{LITERATURA}

Bernardo, Susan M. - Murphy, Graham J.

2006 Ursula K. Le Guin: A Ctitical Companion (Westport: Greenwood Press)

\section{DĚDINOVÁ, Tereza}

2018a „Vyprávět svět - o nepostradatelnosti mimésis ve fantastické literatuře na příkladu Vyprávění Ursuly K. Le Guinové“, Bohemica litteraria 2018, č. 1, s. 138-155

2018b „Žijeme ve fantazii - fantastická literatura jako prostředek proměny mysli a světa“, Bohemica litteraria 2018 , č. 2, s. $145-160$

\section{Nicholds, Peter - Clute, John}

2018 „Le Guin, Ursula K.“, in Clute, John - Langford, David - Nicholls, Peter (eds.) The Encyklopedia of Science Fiction [on line] [cit. 2018-2-09]

NovÁKovÁ, Luisa

2016 „Prolog“, in Dědinová, Tereza (ed.) Na rozhraní světů (Brno: Masarykova univerzita), s. 217-219

Le Guinové, Ursula K.

2019 Proč čist fantasy (Praha: Gnóm), přel. Jakub Němeček

SLADOVÁ, Jana

2007 „Le Guin(ová) Ursula“, in Šubrtová, Milena a kol. Slovník autorů literatury pro děti a mládež I - Zahranični spisovatelé (Praha: Libri 2007), s. 507

ŠUST, Martin

2002 „O autorce“, in Le Guinová, Ursula K. Čaroděj Zeměmoři (Praha: Triton), s. 194-203

TOLKIEN, J. R. R.

2006 Netvoři a kritikové a jiné eseje (Praha: Argo)

Mgr. Luisa Nováková, Ph.D., luisa@phil.muni.cz, Ústav české literatury, Filozofická fakulta Masarykovy univerzity, Brno, Česká republika / Department of Czech Literature, Faculty of Arts, Masaryk University, Brno, Czech Republic 